\title{
Studi Efek Gangguan EMP (Elektromagnetic Pulse) pada Perangkat Elektronik
}

\author{
Jhav Sund Oktoricoento ${ }^{1 *}$, Muhammad Ramdani ${ }^{1}$, Sahrudin $^{1}$, Kun Fayakun ${ }^{1}$, Harry Ramza ${ }^{1}$, \\ Akhiruddin Maddu ${ }^{2}$ \\ ${ }^{1}$ Program Studi Teknik Elektro, Fakults Teknik UniversitasMuhammadiyah Prof. Dr. HAMKA \\ Jalan Tanah Merdeka No 6, Kp Rambutan, Jakarta, Indonesia \\ Telp : +62-21-8400341, Faks : +62-21-8411531, *e-mail : royale.jhavsund@gmail.com; \\ muhammadramdani@uhamka.ac.id; sahrudinace@gmail.com \\ knfayakun@uhamka.ac.id; hramza@uhamka.ac.id; \\ ${ }^{2}$ Departemen Fisika, Fakultas Matematika dan Ilmu Pengetahuan Alam, Institut Pertanian Bogor, \\ Jalan Meranti, Kampus IPB Dramaga, Babakan, Dramaga, Bogor, Jawa Barat 16680 \\ Telp: (0251) 8625481 E-mail : akhiruddin@ipb.ac.id
}

\begin{abstract}
Abstrak - Keberadaan perangkat elektronik pada kehidupan manusia sangat lekat adanya saat ini. Berbagai bidang kehidupan manusia selalu ditunjang oleh perangkat elektronik, dari mulai bidang telekomunikasi hingga bidang keamanan, salah satunya adalah sistem pengawasan (surveillance).Pemanfaatan elektronika dalam bidang militer saat ini dikenal dengan Electronic Warfare (EW).Salah satu jenis serangan elektronik (elektronic attack) adalah electromagnetic jamming. Penelitian ini bertujuan untuk mengkaji tentang pengaruh EMP serta menentukan nilai gangguan dari medan elektromagnetik terhadap sistem pengawasan berupa mini kamera. Variabel dalam melakukan pengukuran terdiri dari tegangan sumber, jarak interferensi, dan lilitan yang masingmasing nilainya divariasikan.Formulasi data pengukuran menggunakan aplikasi Design Expert 11 dengan metode Response Surface D-Optimal. Hasil penelitian menunjukan bahwa nilai fluks magnetik maksimum yang dihasilkan jammer sinyal adalah 0,479 Wb/m2, nilai gangguan maksimum pada level spektrum mini kamera adalah $2 \mathrm{~dB}$, dan nilai gangguan maksimum paling sering terjadi pada frekuensi 4,9 MHz. Nilai koefisien korelasi dari pengaruh medan elektromagnetik terhadap sistem pengawasan antara nilai prediksi simulasi dengan nilai pengukuran langsung adalah -0,55093384.
\end{abstract}

Kata kunci: EMP, Fluks Magnetik, Level Spektrum, jammersinyal, jamming, frekuensi, Arc Generator.

\begin{abstract}
The existence of electronic devices in human life is very close today. Various areas of human life is always supported by electronic devices, ranging from the field of telecommunications to the security field, one of which is the surveillance system. Utilization of electronics in the military field is now known as Electronic Warfare (EW). One type of electronic attack is electromagnetic jamming. This study aims to examine the effect of EMP and determine the value of interference from the electromagnetic field to the surveillance system in the form of mini cameras. Variables in making measurements consist of source voltage, interference distance, and coil that each value is varied. Formulation of measurement data using Design Expert 11 with D-Optimal Response Surface method. The results showed that the maximum magnetic flux value generated by the signal jammer was 0,479 $\mathrm{Wb} / \mathrm{m} 2$, the maximum interference value at the mini camera spectrum level was $2 \mathrm{~dB}$, and the maximum interference value most often occurred at 4,9 MHz. The correlation coefficient value of the influence of the electromagnetic field on surveillance system between the predicted value of the simulation and the direct measurement value is -0,55093384.
\end{abstract}

Keywords :EMP, Magnetic Flux, Spectrum Level, signal jammer, jamming, frequency, Arc Generator.

\section{Pendahuluan}

Keberadaan perangkat elektronik pada kehidupan manusia sangat lekat adanya saat ini.Bahkan dengan adanya perangkat-perangkat elektronik pekerjaan manusia dapat
dipermudah.Berbagai bidang kehidupan manusia selalu ditunjang oleh perangkat elektronik, dari mulai bidang telekomunikasi hingga bidang keamanan, salah satunya adalah sistem pengawasan (surveillance). 
Sehubungan dengan itu, hal yang menjadi fokusnya adalah setiap peralatan elektronika memiliki medan elektromagnet, seperti yang dikemukakan oleh Maxwell pada teorinya, bahwaperubahan medan listrik akan menghasilkan medan magnet, hal ini pula yang menjadi dasar terjadinya fenomena interferensi oleh gelombang elektromagnetik atau disebut dengan EMI (Electromagnetic Interference) yang berada pada lingkup keilmuwan EMC (Electromagnetic Compability)

Teknik jamming sendiri adalah salah satu bentuk dari interferensi/gangguan pada suatu sistem.Perkembangan jamming saat ini sebagian besar adalah untuk pemanfaatan di bidang militer, teknik ini berfungsi mengacaukan sistem keamanan lawan. Selain itu teknik jamming digunakan pada serangkaian test engineering product, untuk menguji ketahanan produk terhadap gangguan.

Sifat interferensi terdapat dua macam yaitu interferensi yang dapat menguatkan ataupun interferensi yang dapat mengganggu/menghilangkan sinyal dari objek yang terinferensi.Teknik seperti ini termasuk ke dalam Electronic Warfare (EW).Peperangan elektronik mengacu pada aksi militer yang melibatkan penggunaan energi elektromagnetik dan diarahkan untuk mengendalikan spektrum elektromagnetik atau untuk menyerang musuh.

Salah satu jenis serangan elektronik (elektronic attack) adalah electromagnetic jamming untuk mencegah atau mengurangi penggunaan spektrum elektromagnetik yang efektif pada musuh, sehingga dapat menurunkan atau menetralkan kemampuan tempur musuh. ${ }^{[1]}$

\section{Dasar Teori}

Jamming adalah cara melumpuhkan komunikasi elektronik dengan cara menimpa atau menutupi sinyal dari suatu pemancar dengan sinyal lain (disebut sinyal jamming) yang mempunyai frekuensi sama dengan pemancar tetapi mempunyai daya atau energi yang lebih besar, sehingga penerima hanya akan mendeteksi sinyal jamming. ${ }^{2]}$

Electronic jamming adalah bentuk dari Electronic Warfare, yaitu ketika jammers meradiasikan sinyal pengganggu (interfering signals) kearah radar lawan, memblok receiver dengan energi sinyal sangat tinggi. Terdapat dua teknik utama yaitu noise techniques dan repeater techniques. Tiga tipe dari noise jamming adalah spot, sweep, dan barrage. ${ }^{[3]}$

\subsection{Prinsip Kerja Jammer Sinyal dengan Pulsa \\ Elektromagnetik}

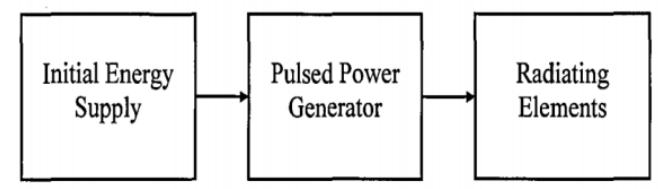

Gambar 2.1 Blok diagram dari sebuah sistem transformasi langsung ${ }^{[4]}$

Cara kerja dari jammer sinyal yaitu dengan cara menimpakan medan elektromagnetik yang sangat besar pada sirkuit elektronik. Medan magnet yang cukup kuat tersebut dapat menginduksi sebuah arus listrik yang terdapat pada hampir semua benda yang bersifat konduktor.

Daya elektromagnetik yang besar ini berasal dari sebuah sumber tegangan DC, lalu tegangan tersebut diubah menjadi tegangan tinggi DC berbentuk spark gap lalu dialirkan melalui lilitan solenoida dan menghasilkan radiasi elektromagnetik berbentuk pulsa berdaya perusak.

\subsection{Prinsip Dasar Arc Generator}

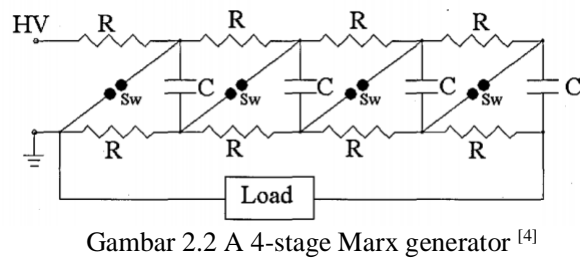

Cara kerja dari high voltage converter yang dipakai pada penelitian ini berfungsi sebagai pulsed power generator sama seperti cara kerja dari rangkaian Marx Generator, yaitu merubah tegangan rendah menjadi tegangan tinggi sehingga menimbulkan spark gap. Pada dasarnya, terjadinya sebuah loncatan listrik (spark gap/arc) hanya ada pada tegangan tinggi.

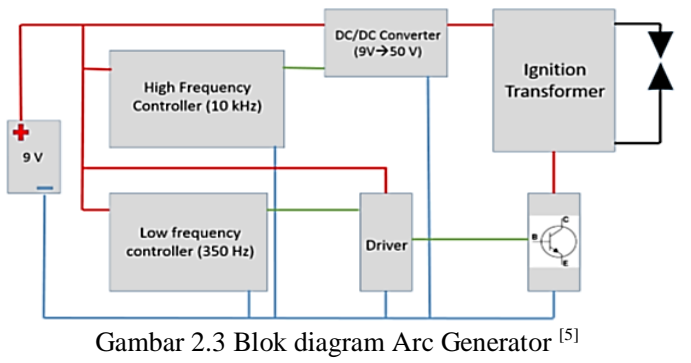

Tegangan sumber dari alat tersebut barasal dari baterai $9 \mathrm{~V}$ (Li-ion).Sumber tersebut dapat menghasilkan arus yang tinggi untuk waktu yang singkat (1-2 detik). Bagian utama dari rangkaian ini adalah transformator yang memiliki perbandingan tegangan 1:100, jadi jika ada tegangan input sebesar $200 \mathrm{~V}$ pada lilitan/coil primer, maka akan menjadi $20 \mathrm{kV}$ pada lilitan sekundernya. [5]

\subsection{Elektromagnetik}

Hans Christian Oersted (1777-1851) mengamati bahwa sebuah magnet yang dapat berputar (jarum kompas) akan menyimpang apabila berada di dekat kawat yang dialiri arus.

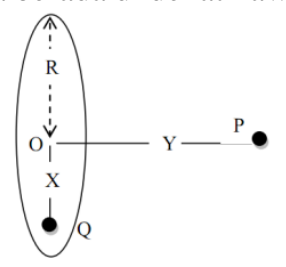

Gambar Error! No text of specified style in document. .4 Kumparan Berjari-Jari R, Titik P Terletak pada Sumbu Kumparan Berjarak Y dari Pusat Kumparan O. Titik Q pada Garis Tengah Kumparan Berjarak X dari $\mathrm{O}^{[6]}$

Nilai medan magnet $\mathrm{B}$ di titik $\mathrm{P}$ diperoleh dari hukum Biot Savart seperti pada persamaan: 


$$
B=\frac{\mu_{0} R^{2} i}{2\left(R^{2}+Y^{2}\right)^{3 / 2}}
$$

Sedangkan di titik $\mathrm{Q}$ yang berada pada garis tengah kumparan berjarak $\mathrm{X}$ dari pusat kumparan, medan magnetnya mengikuti persamaan di bawah.

$$
B=\frac{\mu_{0 N i}}{2 \pi R}\left[\frac{K(X / R)}{1+\frac{X}{R}}+\frac{E(X / R)}{1-\frac{X}{R}}\right]
$$

dengan:

$\mathrm{K}(\mathrm{X} / \mathrm{R})=\mathrm{K}(\psi)$ : integral eliptik jenis pertama $\mathrm{E}(\mathrm{X} / \mathrm{R})=\mathrm{E}(\psi)$ : integral eliptik jenis kedua

Dan

$$
\psi=\sin ^{-1}\left(\frac{2 \sqrt{X / R}}{1+\frac{X}{R}}\right)
$$

\subsection{Mekanisme Induksi Elektromagnetik}

Pancaran dari gelombang elektromagnetik (GEM) dapat menginduksi setiap bahan yang berada disekitarnya terutama bahan logam. Induksi tersebut dapat menghasilkan energi panas pada bahan metal atau noise bila objek terpaan itu berbentuk satu rangkaian elektronik.

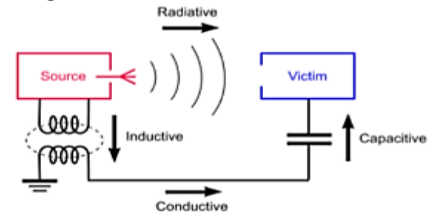

Gambar Error! No text of specified style in document..5 Jalur interferensi energi GEM sampai ke target ${ }^{[7]}$

Terdapat kemungkinan empat jalur yang dilalui sinyal pengganggu untuk mencapai target yaitu, secara konduktif, reaktif, atau secara radiatif. Secara reaktif terbagi menjadi dua jenis, yaitu, magnetic coupling dan electrical coupling.Magnetic coupling disebut sebagai induktif, sedang electrical coupling disebut sebagai hubungan kapasitif.Keempat jalur pengaruh pancaran GEM tersebut ditunjukkan secara skematik pada gambar 2.5.

Pengaruh yang bersifat konduktif terjadi bila sumber dan target tersambung langsung melalui saluran transmisi, atau jalur circuit board. Sedangkan induktif terjadi bila antara sumber dan target dipisahkan dalam jarak yang dekat (kurang dari satu panjang gelombang, $\lambda$ ). Sementara untuk pengaruh secara kapasitif terjadi bila jarak antara sumber dan target sangat dekat yang biasa disebut dengan istilah gap, misalnya antara dua konduktor yang berdekatan sehingga terbentuk satu kapasitor keping sejajar dengan satu nilai kapasitansi tertentu. Dengan demikian, proses terpengaruh secara induktif dan kapasitif dapat terjadi bersama-sama (near-field).

Sementara proses interferensi yang terjadi secara radiatif berlangsung bila sumber dan jarak terpisah relatif jauh yang lebih dari beberapa panjang gelombang, $\lambda$. (OSHA Cincinnati Laboratory, 1990 dalam Djamal, 2013) mengatakan bahwa, jarak yang lebih besar dari $2 \lambda$, interferensi yang terjadi sudah bersifat radiatif (far-field) ${ }^{[7]}$

Pengaruh induksi elektromagnetik dapat menyebabkan satu peralatan elektronik tidak berfungsi sebagaimana mestinya, baik sesaat ataupun beberapa saat atau bahkan permanen. Tidak berfungsinya satu peralatan akibat induksi tersebut dapat dikategorikan menjadi empat kondisi di bawah ini, yaitu :

Permanen dan dapat terukur

- Acak dan tidak berulang, atau akan terjadi bila sumber gangguan muncul

Acak dan tidak berulang, dengan kondisi tidak segera hilang beberapa saat ketika sumber gangguan telah berhenti,

Kerusakan permanen, yaitu ketika beberapa komponen terusakkan. ${ }^{[7]}$

\section{Metodologi Penelitian}

\subsection{Blok Diagram Perancangan Penelitian}

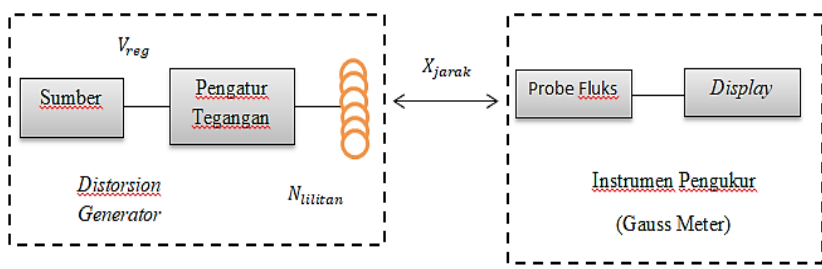

Gambar Error! No text of specified style in document. 1 Perancangan Penelitian Fluks Magnetik

Blok diagram diatas merupakan perancangan penelitian untuk mencari nilai fluks magnetik dari jammer sinyal.

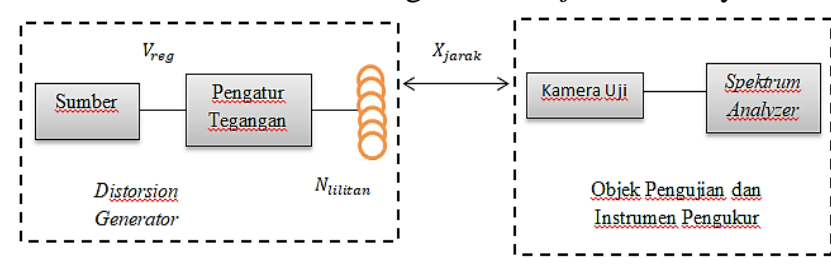

Gambar 3.2 Perancangan Penelitian Pengaruh Interferensi pada Level Spektrum

Blok diagram diatas merupakan perancangan penelitian untuk mencari nilai pengaruh gangguan/interferensi dari jammer sinyal terhadap frekuensi mini kamera.

\subsection{Perancangan Jammer Sinyal}

\subsubsection{Rangkaian Jammer Sinyal}

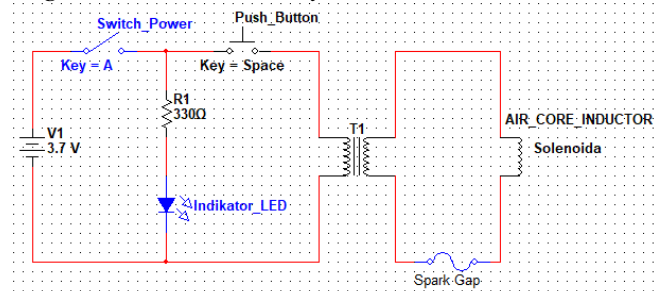

Gambar Error! No text of specified style in document. 3 Skema Rangkaian Jammer Sinyal

Perancangan jammer sinyal dibuat sesuai dengan skematik rangkaian seperti gambar diatas, dengan tegangan sumber 
sebesar 3,7 V - $6 \mathrm{~V}$ dan sumber tegangan tersebut akan diatur dengan rangkaian pengatur tegangan, sebagai pembangkit spark gap/arc penulis menggunakan High Voltage Converter/Arc Generator dengan tegangan yang dikeluarkan sebesar $1000 \mathrm{kV} \mathrm{DC}$.

Lilitan tembaga berbentuk solenoida berfungsi untuk membangkitkan medan elektromagnetik di sekitar kumparan. Diameter lilitan solenoida adalah $5,3 \mathrm{~cm}$ dan rentang spark gap/arc adalah 1-2 cm.

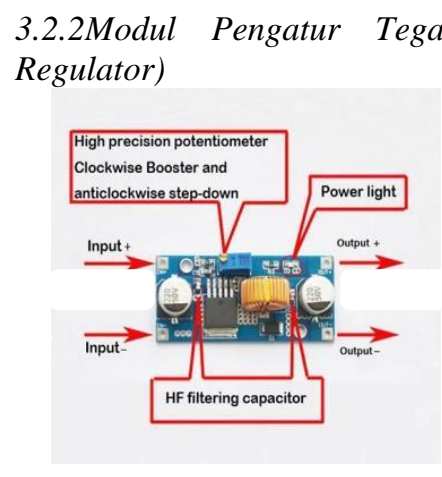

[a]

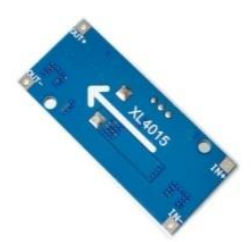

[b]
Gambar Error! No text of specified style in document..4 Modul XL4015 dengan tampak depan [a] dan belakang $[\mathrm{b}]^{[8]}$

Modul pengatur tegangan (adjustable voltage regulator) berfungsi untuk mendapatkan variabel nilai dari sumber tegangan jammer, tipe regulator tegangan yang digunakan yaitu, tipe XL4015 DC to DC Converter.XL4015 adalah sebuah step-down konverter DC/DC dengan rangkaian kontrol PWM yang mampu mengeluarkan arus konstan sebesar 5 A, pengaturan tegangan menggunakan potensiometer berpresisi tinggi, spesifikasinya sebagai berikut. $^{[9]}$

- Tegangan masukan adalah $8 \mathrm{~V}-36 \mathrm{~V}$

- Tegangan keluaran yang dapat diatur adalah

$$
1,25 \mathrm{~V}-32 \mathrm{~V}
$$

- Arus keluaran konstan sebesar $5 \mathrm{~A}$

- Efisiensi tinggi hingga $96 \%$

- Frekuensi switching tetap sebesar $180 \mathrm{KHz}$

- Minimum Drop Out 0,3 V

\subsection{Parameter Pengujian Alat}

Tabel 3.1 Parameter Pengaruh Interferensi pada Level Spektrum

\begin{tabular}{cccc}
\hline No. & Parameter & Satuan & Fungsi \\
\hline 1. & Tegangan Supply & volt & Input \\
2. & Jumlah Lilitan & gulungan & Input \\
3. & Jarak Interferensi & $\mathrm{cm}$ & Input \\
4. & Level Spektrum & $\mathrm{dB}$ & Output \\
\hline
\end{tabular}

Parameter pengujian penelitian ini, seperti tampak pada tabel 3.1 yaitu tegangan sumber, jumlah lilitan, dan jarak interferensi yang masing-masing diberi nilai bervariasi, untuk tabel pertama nilai level spektrum menandakan pengaruh dari interferensi jammer sinyal pada sistem. Frekuensi spektrum yang dilihat yaitu pada rentang $4,4 \mathrm{MHz}$ $-5,5 \mathrm{MHz}$.
Tabel 3.2 Parameter untuk Fluks Magnetik ( $\Phi)$

\begin{tabular}{cccc}
\hline No. & Parameter & Satuan & Fungsi \\
\hline 1. & Tegangan Supply & volt & Input \\
2. & Jumlah Lilitan & gulungan & Input \\
3. & Jarak Interferensi & $\mathrm{cm}$ & Input \\
4. & Fluks Magnetik & $\mathrm{Wb} / \mathrm{m}^{2}$ & Output \\
\hline
\end{tabular}

Tabel 3.2 menunjukan parameter pengujian yang sama, tetapi fungsi tabel berbeda yaitu, untuk melihat seberapa besar nilai fluks magnetik yang dihasilkan oleh jammer sinyal. Kemudian nilai hasil pengukuran akan disajikan dalam bentuk grafik korelasi pengaruh besarnya medan magnet terhadap sistem pengawasan.

\section{Temuan dan Pembahasan}

Proses pengolahan data hasil pengujian dilakukan pada aplikasi Design Expert 11 dengan metode Response Surface D-Optimal sebagai konsep Design of Experiment (DoE). (Harry, 2018) menyatakan bahwa DoE merupakan sebuah pendekatan terencana untuk menentukan penyebab atau efek keterkaitan, serta metode ini digunakan untuk setiap proses dengan nilai masukan dan keluaran yang terukur. ${ }^{[10]}$

Design of Experiment (DoE) terkadang disebut pula sebagai Multifactor Testing (MFT) adalah hal yang mendasar dan penting untuk meningkatkan pemahaman dari sebuah produksi atau proses. Menurut (Montgomery, 2009 dalam Antony, 2011) DoE adalah perangkat yang dapat memungkinkan efek dari beberapa sistem atau variabel proses untuk dicari secara bersamaan dan efisien, hasilnya mengarah ke pemahaman tentang sistem. ${ }^{[11]}$

\subsection{Persamaan Aktual dari Simulasi}

\subsubsection{Persamaan Aktual Fluks Magnetik}

Persamaan akhir untuk faktor aktual pada Fluks Magnetik dapat diberikan:

Fluks Magnetik $=-0.720495+0.420108 *$ Tegangan + $0.032864 *$ Jarak $+0.0056 *$ Lilitan $-0.033057 *$ Tegangan

* Jarak $+0.009206 *$ Tegangan * Lilitan $-0.003141 *$ Jarak

$*$ Lilitan $-0.076582 *$ Tegangan $^{2}+0.009505 *$ Jarak $^{2}-$ $0.001329 *$ Lilitan $^{2}+2.7 \times 10^{-5} *$ Tegangan $*$ Jarak $*$ Lilitan $+0.001160 *$ Tegangan $^{2} *$ Jarak $-0.000593 *$ Tegangan $^{2} *$

Lilitan $+0.001386 *$ Tegangan $*$ Jarak $^{2}-0.000126 *$

Tegangan $*$ Lilitan $^{2}+7.4898 \times 10^{-6} * \mathrm{Jarak}^{2} *$ Lilitan + $0.000104 *$ Jarak $^{*}$ Lilitan $^{2}+0.005402 *$ Tegangan $^{3}-$ $0.000796 * \operatorname{Jarak}^{3}+2.8 \times 10^{-5} *$ Lilitan $^{3}$ [dalam satuan $\left.\mathrm{Wb} / \mathrm{m}^{2}\right] \quad(4.1)$

\subsubsection{Persamaan Aktual Gangguan pada Level Spektrum}

Persamaan akhir untuk faktor aktual pada level spektrum di frekuensi 4,4 MHz-5,5 MHz dapat diberikan: 
Tabel 4.1 Persamaan Aktual Gangguan pada Level Spektrum

\begin{tabular}{|c|c|c|}
\hline No. & $\begin{array}{c}\text { Frekuensi } \\
\text { (MHz) }\end{array}$ & Bentuk Persamaan \\
\hline 1. & 4,4 & 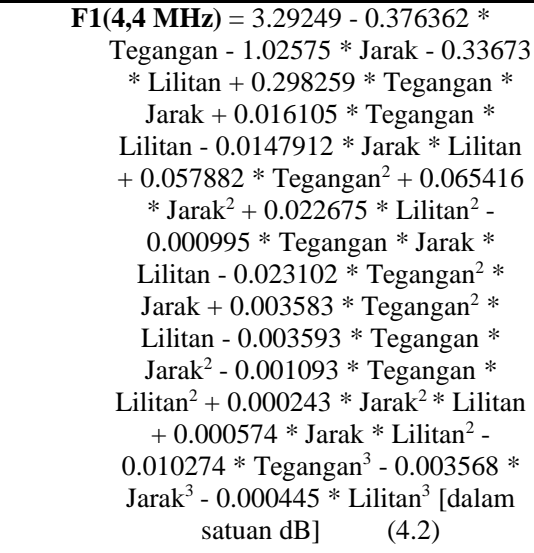 \\
\hline 2. & 4,5 & 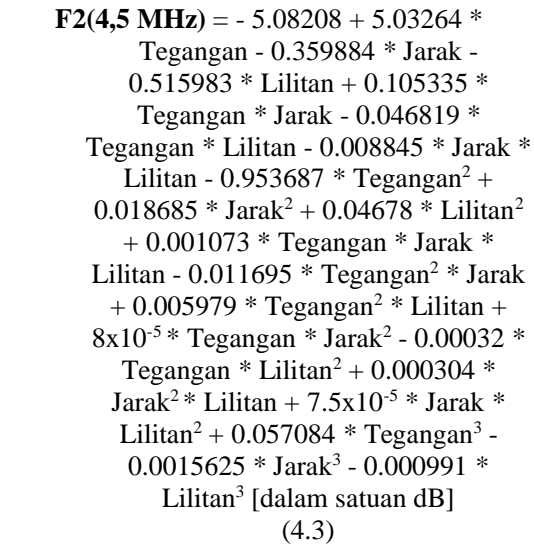 \\
\hline 3. & 4,6 & $\begin{array}{c}\text { F3(4,6 MHz) }=-1.42968+1.38905 * \\
\text { Tegangan }-0.204455 * \text { Jarak }- \\
0.063831 * \text { Lilitan }+0.018223 * \\
\text { Tegangan * Jarak }+0.011441 * \\
\text { Tegangan * Lilitan }-6.9 \times 10^{-5} * \text { Jarak }^{*} \\
\text { Lilitan }+-0.162995 * \text { Tegangan }{ }^{2}+ \\
\text { 0.006518* Jarak }+0.000155 * \text { Lilitan }^{2} \\
\text { [dalam satuan dB] }\end{array}$ \\
\hline 4. & 4,7 & 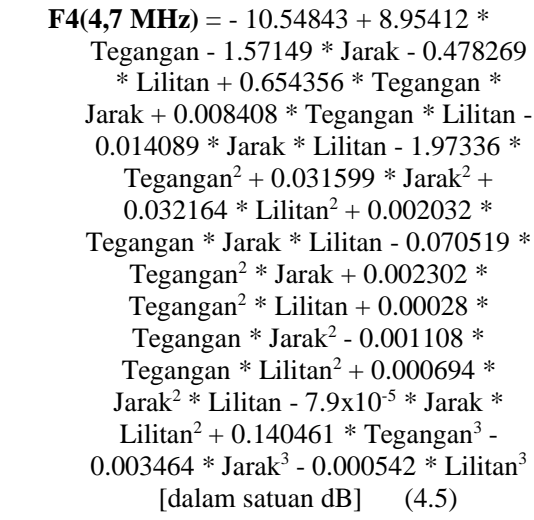 \\
\hline 5 . & 4,9 & $\begin{array}{c}\text { F5 (4,9 MHz) }=-1.204+1.33943 * \text { Tegangan } \\
-0.180271 * \text { Jarak }-0.049364 * \text { Lilitan } \\
+0.024131 * \text { Tegangan * Jarak }+ \\
0.008834 * \text { Tegangan } * \text { Lilitan }- \\
0.00122 * \text { Jarak }^{*} \text { Lilitan }-0.168919 * \\
\text { Tegangan }{ }^{2}+0.002902 * \text { Jarak }^{2}+ \\
0.000267 * \text { Lilitan }^{2}[\text { dalam satuan dB] } \\
(4.6)\end{array}$ \\
\hline
\end{tabular}

\begin{tabular}{|c|c|c|}
\hline 6. & 5,0 & 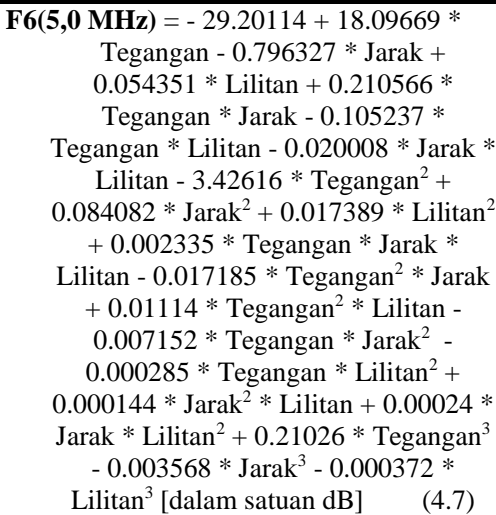 \\
\hline 7. & 5,2 & 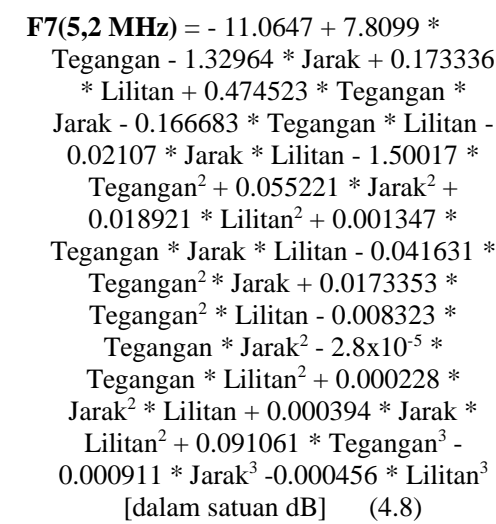 \\
\hline 8. & 5,3 & $\begin{array}{c}\text { F8 }(\mathbf{5}, 3 \mathbf{M H z})=-1.49653+1.4851 * \\
\text { Tegangan }-0.262434 * \text { Jarak }- \\
0.054496 * \text { Lilitan }+0.020232 * \\
\text { Tegangan * Jarak }+0.008644 * \\
\text { Tegangan * Lilitan }-0.000551 * \text { Jarak }^{*} * \\
\text { Lilitan - 0.181479* } \text { Tegangan }^{2}+ \\
\text { 0.013348* Jarak }{ }^{2}+0.00036 * \text { Lilitan }^{2} \\
\text { [dalam satuan dB] }\end{array}$ \\
\hline 9. & 5,5 & $\begin{array}{c}\text { F9 }(5,5 \text { MHz })=0.309476+0.809761 * \\
\text { Tegangan }-0.280689 * \text { Jarak - } \\
0.084538 * \text { Lilitan }+0.019919 * \\
\text { Tegangan * Jarak }+0.014468 * \\
\text { Tegangan * Lilitan }-0.000137 * \text { Jarak }^{*} * \\
\text { Lilitan }-0.117528 * \text { Tegangan }^{2}+ \\
\text { 0.015089* Jarak }{ }^{2}+0.000202 * \text { Lilitan }^{2} \\
{[\text { dalam satuan dB] }}\end{array}$ \\
\hline
\end{tabular}

4.2 Validasi Data

Sampel data untuk divalidasi merupakan data maksimum dari masing-masing respon.

Tabel 4.2 Validasi Data Fluks Magnetik $(\Phi)$

\begin{tabular}{ccc}
\hline $\begin{array}{c}\text { Parameter } \\
\text { Pengujian }\end{array}$ & Nilai & Satuan \\
\hline Tegangan & 6 & volt \\
Jarak & 0 & $\mathrm{~cm}$ \\
Lilitan & 15 & gulungan \\
\hline Hasil & Nilai & Satuan \\
\hline Pengukuran & 0,479 & $\mathrm{~Wb} / \mathrm{m}^{2}$ \\
Prediksi & 0,427 & $\mathrm{~Wb} / \mathrm{m}^{2}$ \\
\hline
\end{tabular}

Tabel 4.2 diatas menunjukkan perbandingan antara nilai Fluks Magnetik yang didapat dari pengukuran langsung dengan nilai simulasi DoE. 
Tabel 4.3 Validasi Data Gangguan pada Level Spektrum

\begin{tabular}{cccc}
\hline No. & $\begin{array}{c}\text { Frekuensi } \\
(\text { MHz) }\end{array}$ & $\begin{array}{c}\text { Hasil yang Diperoleh } \\
\text { Prediksi } \\
\text { (dB) }\end{array}$ & $\begin{array}{c}\text { Pengukuran } \\
\text { (dB) }\end{array}$ \\
\hline 1. & 4,4 & 1,5741 & 1,8 \\
2. & 4,5 & 1,3772 & 1,8 \\
3. & 4,6 & 1,4114 & 1,8 \\
4. & 4,7 & 1,2581 & 1,8 \\
5. & 4,9 & 1,213 & 2 \\
6. & 5 & 1,5548 & 1,8 \\
7. & 5,2 & 1,5109 & 1,8 \\
8. & 5,3 & 1,3477 & 1,8 \\
9. & 5,5 & 1,6565 & 1,8 \\
\hline \multicolumn{3}{c}{ Korelasi } & $-0,55093384$ \\
\hline
\end{tabular}

Tabel 4.3 diatas menunjukkan perbandingan antara nilai gangguan pada Level Spektrum dengan respon frekuensi, yang didapat dari pengukuran langsung dengan nilai simulasi DoE.

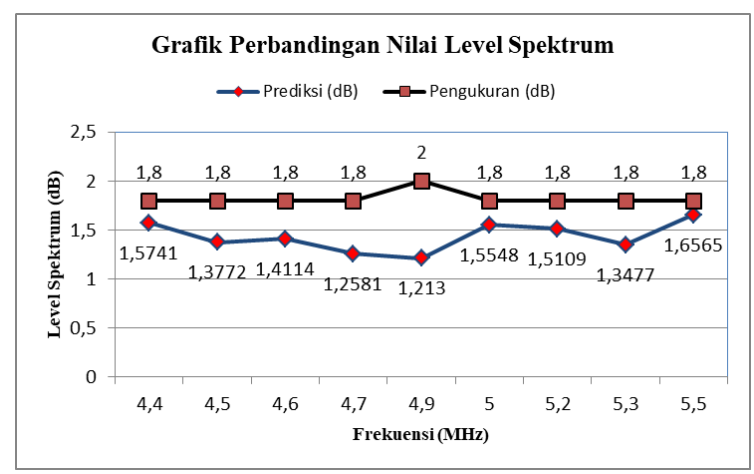

Gambar 4.1 Grafik Perbandingan Nilai Level Spektrum

Gambar grafik diatas menunjukkan perbandingan nilai level spektrum, antara nilai yang dihasilkan dari pengukuran langsung dengan nilai hasil prediksi melalui persamaan aktual dari simulasi DoE terhadap frekuensi uji yang diganggu atau mengalami interferensi.

Nilai korelasi yang didapat dari perbandingan tersebut, yaitu -0,55093384 sehingga memiliki hubungan yang moderat antara nilai prediksi dengan nilai pengukuran, karena $-0,70<r<-0,50$. Jenis koefisien korelasi $(r)$ yang dihasilkan adalah koefisien korelasi negatif, artinya bila nilai $\mathrm{X}$ naik maka nilai $\mathrm{Y}$ turun dan sebaliknya. Jenis koefisien korelasi ini terletak antara $-1<r<0$.

Jika $\mathrm{X}$ adalah nilai prediksi, $\mathrm{Y}$ adalah nilai pengukuran, dan nilai koefisien intercept yang muncul seperti terlihat pada tabel dibawah ini, maka bentuk persamaan yang terjadi sebagai berikut.

$$
Y=-1,611 .[X]+3,535
$$

Tabel 4.4 Tabel ANOVA untuk Perbandingan Nilai Prediksi dengan Nilai

\begin{tabular}{|c|c|c|c|c|c|c|c|c|}
\hline \multicolumn{9}{|c|}{ Pengukuran } \\
\hline & $\begin{array}{c}\text { Coef } \\
\text { ficie } \\
\text { nts }\end{array}$ & $\begin{array}{c}\text { Stan } \\
\text { dard } \\
\text { Erro } \\
\quad r\end{array}$ & $\begin{array}{c}t \\
S t a \\
t\end{array}$ & $\begin{array}{l}P- \\
\text { val } \\
\text { ue }\end{array}$ & $\begin{array}{c}\text { Lo } \\
\text { wer } \\
95 \\
\%\end{array}$ & $\begin{array}{c}U p \\
\text { per } \\
95 \\
\%\end{array}$ & $\begin{array}{c}\text { Lo } \\
\text { wer } \\
95, \\
0 \%\end{array}$ & $\begin{array}{c}\text { Up } \\
\text { per } \\
95, \\
0 \%\end{array}$ \\
\hline Interc & 3,53 & 1,32 & 2,6 & 0,0 & 0,2 & 6,7 & 0,2 & 6,7 \\
\hline ept & 5 & 9 & 59 & 37 & 83 & 88 & 83 & 88 \\
\hline 1,8 & $\begin{array}{c}- \\
1,16 \\
1\end{array}$ & $\begin{array}{c}0,72 \\
8\end{array}$ & $\begin{array}{c}- \\
1,5 \\
95\end{array}$ & $\begin{array}{c}0,1 \\
62\end{array}$ & $\begin{array}{c}- \\
2,9 \\
42\end{array}$ & $\begin{array}{c}0,6 \\
19\end{array}$ & $\begin{array}{c}- \\
2,9 \\
42\end{array}$ & $\begin{array}{c}0,6 \\
19\end{array}$ \\
\hline
\end{tabular}

\section{Kesimpulan}

Berdasarkan hasil penelitian yang telah dilakukan, yaitu pengujian tentang pengaruh EMP (Electromagnetic Pulse) pada sistem pengawasan, maka diperoleh kesimpulan sebagai berikut.

1. Nilai medan magnetik yang mengganggu sistem secara maksimum dengan nilai gangguan sebesar $2 \mathrm{~dB}$ adalah $0,226 \mathrm{~Wb} / \mathrm{m} 2$ pada frekuensi $4,9 \mathrm{MHz}$, jika kondisi variabel: jarak $=0 \mathrm{~cm}$, tegangan $=3,7 \mathrm{~V}$, dan lilitan $=20$.

2. Nilai koefisien korelasi pengaruh medan elektromagnetik terhadap sistem pengawasan adalah $-0,55093384$, nilai ini dihasilkan dari perbandingan nilai prediksi simulasi dengan nilai pengukuran langsung, nilai yang diambil merupakan nilai maksimum dari setiap frekuensi yang diamati.

3. Persamaan aktual yang dihasilkan dari gangguan EMP yaitu

a) Untuk menentukan fluks magnetik dapat dilihat pada persamaan (4.1)

b) Unutk menentukan besarnya nilai pengaruh interferensi level spektrum pada mini kamera, dapat dilihat pada persamaan (4.2) hingga persamaan (4.10) untuk masing-masing parameter frekuensi yang diamati, yaitu 4,4 MHz-5,5 MHz.

\section{Penghargaan}

Terima Kasih banyak kepada semua pihak yang telah membantu dalam penyelesaian penelitian ini.

\section{Kepustakaan}

[1] US Army. FM3-12 Cyberspace and Electronic Warfare Operations. vol. 5. no. 17-2. April 2017. Washington DC : Army Publishing Directorate.

[2] Suhendro, Budi, Djiwo Harsono, dkk. Modifikasi dan Otomasi 'Handheld' Jammer Berbasis Mikrokontroler ATMEGA 8535. pp. 388-394. 2012. Yogyakarta. Seminar Nasional VIII SDM Teknologi Nuklir. ISSN 1978-0176.

[3] Rustamaji, E. Djaelani. Radar Jamming Suatu Konsep Rancang Bangun. vol. 11. no. 2. pp. 71-80. September 2012. Bandung : J. Electrans. ISSN 1412 - 3762.

[4] Sarkar, Partha. A Compact And Portable EMP Generator Based on Tesla Transformer Technology (Thesis). UK: Loughborough University, 2008. hal 23-24.

[5] Eckl, Bence dan Szabo Norbert. Design And Simulation Of Electric Arc Generator Device. April 2016. Hungaria : University of Miskolo. ISBN 978-963-358-113-1.

[6] Anggoro, C. J. dan I. E. Santosa. Distribusi Medan Magnet di Sekitar Kumparan Berarus Listrik.vol. 2. pp. 6-9. ISSN : 0853-0823. 
Yogyakarta : Prosiding Pertemuan Ilmiah XXIX HFI Jateng \& DIY, 25 April 2015.

[7] Djamal, Hidajanto, Iwan Krisnadi. 2013. Gangguan Telepon Seluler Pada Transportasi Udara Komersial. pp. 119-144. Vol. 4.no.2. Incom Tech, Jurnal Telekomunikasi dan Komputer.

[8] Gambar modul

XL4015.

(https://www.google.com/search?q=modul+xl4015, diakses 02 Juli 2018)

[9] XLSEMI Datasheet. Datasheet $180 \mathrm{KHz} 36 \mathrm{~V}$ Buck DC to DC Converter Features XL4013 General Description Datasheet 4A
$180 \mathrm{KHz} 36 \mathrm{~V}$ Buck DC to DC Converter Pin Configurations. pp. 1 10. (https://datasheetspdf.com/pdf/786208/Xlsemi/XL4015/1, diakses 02 Juli 2018)

[10] H. Ramza et al. 2018. Pemodelan Medan Magnetik Dua Kawat Gulungan Helmholtz Modelling of Two Helmholtz Coils Magnetic. pp. 259-276. No. 27.Vol. 07.Ukrida : Jakarta.

[11] J. Antony, S. Coleman, D. C. Montgomery, M. J. Anderson, and R. T. Silvestrini. 2011. Design of Experiments For Non-Manufacturing Processes: Benefits, Challenges and Some Examples. Proc. Inst. Mech. Eng. Part B J. Eng. Manuf. vol. 225.no. 11. pp. 2078-2087. 